\title{
Non- Bank Islamic Mortgage in Maqashid al-Sharia Perspective
}

\author{
Fahmi Syam, Afifuddin Kadir², Ayesha Nur Salma3 \\ ${ }^{1}$ Universitas Borneo, ${ }^{2}$ Institut Agama Islam As-Siddiq, 3Universitas Muhammadiyah \\ Pekajangan Pekalongan \\ E-mail: fahmisyam@gmail.com
}

\begin{abstract}
,
Home mortgage or KPR is regarded as an alternative answer for possessing a house recently, Home mortgage should be possible either through Conventional bank and sharia bank. However, recently there have been new alternatives of owning home by using nonbank Islamic mortgage. Where the mortgage can presently be directly handled by the developer without involving the bank. The issues of this Paper are describing the opinion that non-Bank Islamic Mortgage is more sharia than Islamic Banking in providing Islamic Housing, such as no BI Checking, no riba, no fines, no confiscation, and etc. The purpose of this research is to identify the scheme of non-bank Islamic Mortgage, and analyse the scheme in Maqasid Sharia perspective as Importance foundation in religion. The methods in this study are descriptive analysis research. The data used is secondary data and data collection techniques are literature studies. After discussing, the results showed that Non-Bank Islamic Mortgage cause a lot of harm in term of customer and sharia developer it self in Maqāsid Sharia perspective.
\end{abstract}

Keywords: Islamic Mortgage, Maqashid Al-Sharia, Non-Bank, Riba

\section{INTRODUCTION}

One of the Principles of human needs besides eating, clothing is to have a home. Home is the most expensive asset owned by someone during his lifetime, so that all ways are done to get the desired home and one of ways to get the desired home is to use the credit scheme through Sharia banking. In practice, people will go through the bank as intermediary to help have the desired home, and one of the propensities to choose the sharia bank because it is believed to be free from Riba, and also akad that is not allowed in Shariah.

Home Mortgage is one of the types of services provided by the bank to the customers who are to obtain loans in the housing loan. House ownership credits arise because there is a high need among the community to be able to have a home. House ownership credits are initially one of the products issued by conventional banks. However, along with its development, financing schemes or home loans are also carried out in Islamic banks. Financing scheme or house credit in sharia banks, involving three parties, namely developers as a home maker, the customer as the party who ordered the house and bank as an intermediary. And the agreement used in various akad, Generally use Murabahah Akad (Buy sell reiterate profit) in which the bank acts as the seller and consumer as buyer. The other Akad is also used Musyarakah Mutanaqisah (MMQ) which is a derivative between partnership and lease or Ijarah (Smolo.E \& Hasan, 2011).

However, lately there are new alternatives that arise when one wants to have a home that is using a credit scheme but without a Bank as an intermediary, or a house ownership credit without a sharia Bank. It is meant that sharia mortgage without the intermediation of sharia financial institutions such as banks, buyers or customers are 
immediately instalment to property developers. This scheme only involves developers and consumers only.

The Emergence of a group of developers carrying the concept of Sharia developers, generally that the products they offer are assessed more sharia than sharia banks, especially in-home mortgage. The results of the research conducted by egi arvian shows that the reason of the customer chooses the Non-bank Islamic Mortgage, that the house ownership credit practice in Sharia Bank is not in accordance with Sharia, there are about $55.2 \%$ of the customers or the public who said that (Firmansyah E. A., 2017). Among the reasons not to comply with Sharia Bank Syariah is the application of $B I$ Checking, fines, collateral, confiscated collateral, and also the problematic Akad. Thus, Non-bank Islamic mortgage has some points believed to be a differentiator in home mortgage with sharia banks.

The advertisements submitted indirectly in fact described the quality of sharia Bank which is deemed that contract (akad) practice is not in accordance with Sharia perspective. So the purpose of this research would like to further review the practice of the agreement in the Sharia Bank as well as the non-bank home mortgage that is reviewed in the perspective of Maqāsid Syarī'ah as an important foundation in religion.

In principle, the perspective of Maqāsid Syarī'ah is not detached to the welfare of mankind, the sharia comes to bring benefits to all mankind with the principle of teaching is easily acceptable and is always relevant to the development of the era (Saalih Li era). The aspect of Islamic Sharia as well as its relevance to the development of this era revealed the universality of Islam (Alamiyyah) itself. The universality of Islamic teachings to spread the welfare for all the people is Maqashid Syari'ah (Auda J. , 2011). This Mashlahat (welfare) to be seen in the practice of house ownership credits through the Bank or without through a Bank as an intermediary.

So, it is hoped in this article to answer whether the house ownership credit without the Bank, without the confiscated, without fines, without collateral in accordance with the principle in achieving the benefits as a goal of the Islamic religion or Maqashid Syari'ah.

\section{LITERATURE REVIEW}

\section{Islamic Mortgage Through Sharia Bank}

Home ownership credits are one of the types of services provided by the Bank to customers to obtain loans of housing credits. House ownership credits arise because there is a high need among the community to be able to have a home. And house ownership credits are commonly run by conventional banking that the products can certainly not be separated from interest.

To avoid a RIBA-based product on home ownership credits then Sharia banking is rated as a solution. The difference between conventional home ownership credits and Sharia house ownership credits can be seen from the Akad or contract. If conventional home ownership credits use the interest system, the sharia mortgage is not allowed to use interest instruments in the calculation of installments. In Sharia 
bank transactions are not known terms of interest or interest fee, but use the share system, because the interest is considered RIBA. In the Sharia mortgage product, the customer can also get benefit, which is when the customer wants to settle the payment before the expiry of the contract then the sharia bank will not give a penalty on home financing. Because the price of home ownership credit has been set since the start (fixed rate). This is in different terms with conventional home ownership credits that use the interest system that caused installments to change. In other words, the public housing credit system offered by conventional banking clearly does not comply with Sharia because it contains the element of Riba (Sholihin, 2008).

This principle is used as a foothold to develop sharia products, Sharia mortgage is one of the alternatives for people to get all the needs related to housing with sharia contract. This is also due to all banking activities, whether the funding and financing of business activities must be based on a fatwa issued by the National Sharia Board (DSN) institution that has the authority to organize the Sharia financial course to comply with Islamic sharia. And fatwa DSN MUI must be followed by sharia financial institution in accordance with the mandate of LAW No. 21 on Sharia banking.

The agreement used in sharia banking in Sharia mortgage schemes is Akad Murabahah, Ijarah Muntahiya Bittamlik, musyarakah mutanaqisah (Heykal, 2014). In Akad Murabahah, the concept of trade-based trading which the payment is carried out formidable or instalment. In this contract, the sharia bank acts as the seller who will make the asset sale to its customers in a formidable or in installments. In the Murabahah contract, sharia bank will make the sale of merchandise to its customers with a profit that has been agreed by both parties. Sharia mortgage agreement that uses the Murabahah system makes the sharia bank should inform the customers with regards to the acquisition price of the house obtained by Sharia bank from the developer. Then sharia bank with the price then set the profit that will be taken where the profit margin is agreed by both parties.

That advantage is the profit margin that the value remains during the term of the agreement. With the fixed margin of profit, the installment amount that must be paid by the customer to the sharia bank will not be changed nor will it be incriminated by the customer. This is what distinguishes between sharia banks and conventional banks.

Based on the concept of Syariah house ownership credit, the determination of the price and also the profit in the sharia mortgage must fulfill some important things, namely: (a) The profit requested by the sharia bank and also must be clearly known by the customer; (b) The selling price of the bank which is the purchase price of the bank plus the profit taken by the bank; (c) The selling price which may not change during the term of the Agreement; (d) A mutually agreed payment system (Haris, 2007).

So murabahah can be interpreted to buy and sell goods at the cost of the item plus with an agreed profit margin. Based on definition, the bank will first buy the goods ordered by the customer according to the specifications submitted by the customer and sell it to the customer. The sales price offered to the customer is the purchase price of the supplier plus the profit margin that has been agreed on both sides (Muhammad, 2016). 
Figure 1. Murahabah Financing Scheme

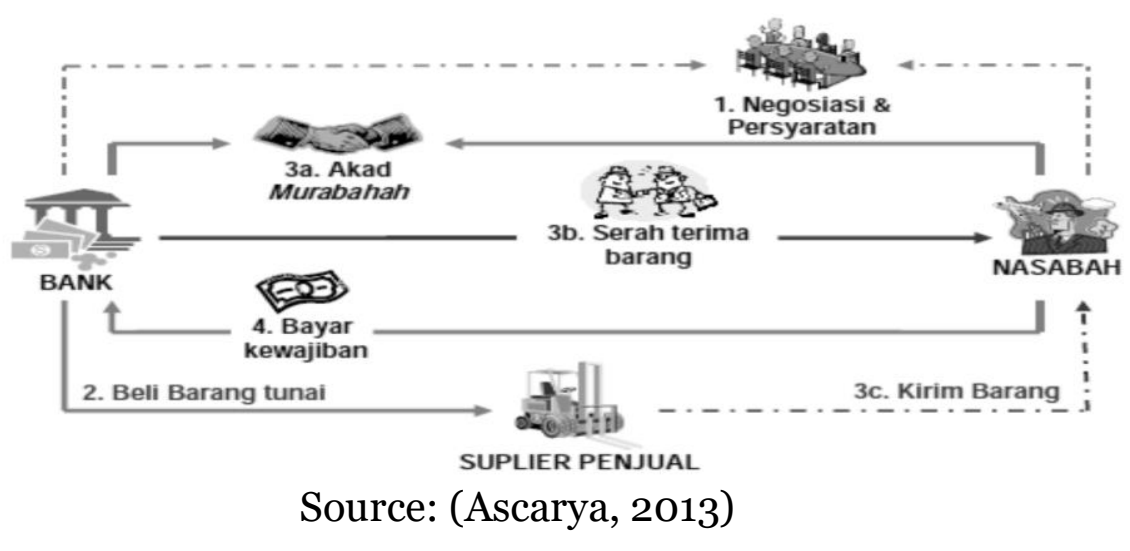

Besides Akad Murabahah, there are also other Akad that can be used that Is Akad Ijarah muntahiyah Bit Tamlik. This agreement is basically a combination of Akad Ijarah (lease) with buying and selling. That is, starting from the lease and ending with the sale or purchase of goods referred at the end of the period (Ascarya, 2013). For example, a customer wants to need a house, the bank will buy the house first, then give use of the house benefits through lease contract (Ijarah), then there is the process of buying and selling of ownership at the end of the period. So, eventually the House transferred ownership from the bank to the customer.

Figure 2. Ijarah Muntahiya Bit Tamlik Financing Scheme

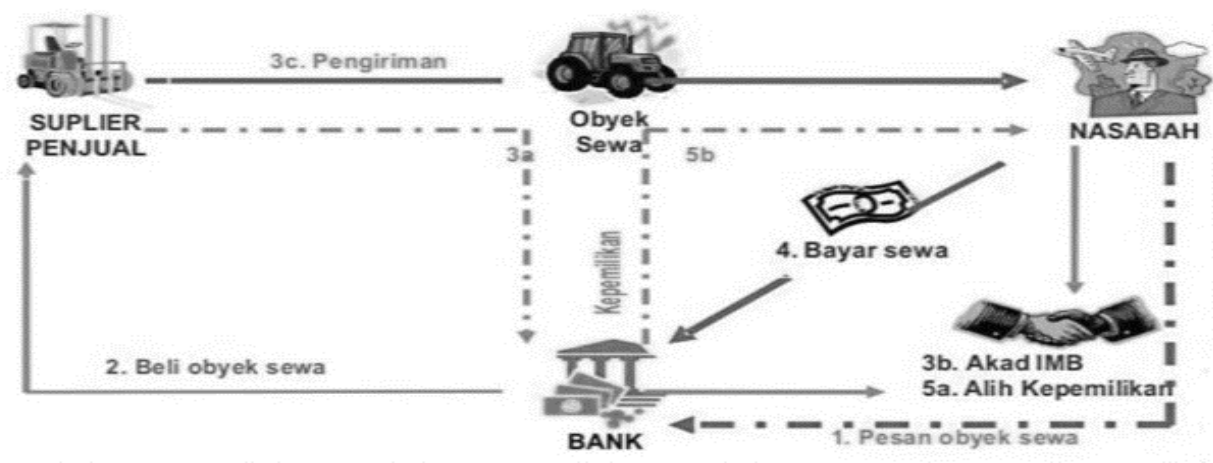

Source: (Ascarya, 2013)

The next Akad used in sharia mortgage is a Musyarakah Mutanaqisah. This Akad is a derivative product of the Musyarakah contract, which is a form of joint agreement between two or more Parties (Hosen, 2009). Implementation in Sharia banking operations is the cooperation between Sharia Bank and the customer to procure or purchase an item (item). Where the assets of the goods belong together. The size of ownership can be determined according to the amount of capital or funds included in the cooperation contract. The customer will then pay a certain amount of capital or funds owned by the Sharia bank. Transfer of ownership from a portion of Sharia bank to the customer along with increasing the amount of customer capital from the increase of customer's installments. Until the end of installment means ownership of an item or object is fully belong to the customer. The decline of sharia 
bank ownership of goods or objects decreases proportionally according to the magnitude of the installment.

Figure 3. Musyarakah Financing Scheme

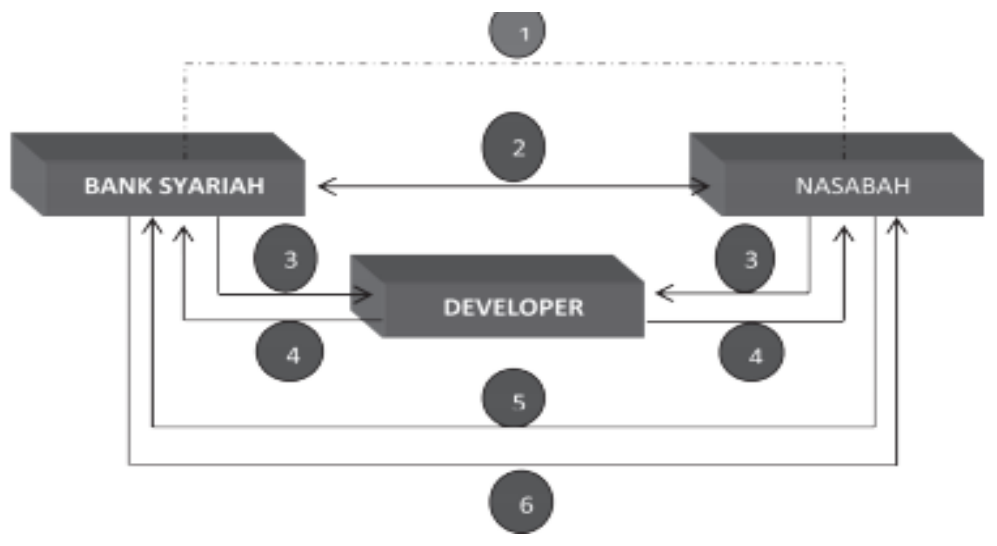

Source: Hosen (2009)

The scheme starts from the negotiations relating to the instalment and lease between the customer and sharia bank, and then proceeds to the agreement or contract of cooperation, and then the purchase of the goods either done by the bank or the customer, and then to obtain the files and documents, and further the customer pays the instalment and lease, and in the end Sharia banks submit ownership rights to the customer.

\section{Non-Bank Islamic Mortgage (KPR)}

Unlike the contract scheme that the sharia bank practiced, on this scheme, the home buyers no longer use the bank, or use the bank's services but the home buyers will be directly related to the Developer such as paying monthly installments to the property developer. So, it looks different from the usual scheme of use, which is to eliminate the role of the bank as a third party that helps the home ownership process, but involving a notary who serves as a third party functioned as a party legalizing legal transactions.

According to their perspective in mortgage scheme, without bank is more flexible because it has different features of the scheme that has been applied in sharia banks, such as no BI Checking, without the seized, without fines, and without Riba, (Egi Arvian Firmansyah, 2017). These features are then promoted by the developers of various digital platforms such as websites, Facebook, Instagram and Whatsaap. The payment of the financing price is fixed and not changed after the contract and payment of the DP (Down payment) with a clear timeframe, although the house price and financing cost value experienced the price increase but the Developer still does not apply prices according to interest rates or RIBA, so the selling price is not changed since from Akad (Muhammad Rizki Hidayah, 2018). The schemes used can be illustrated as follows: 
Figure 3. Non-Bank Sharia Mortgage Scheme

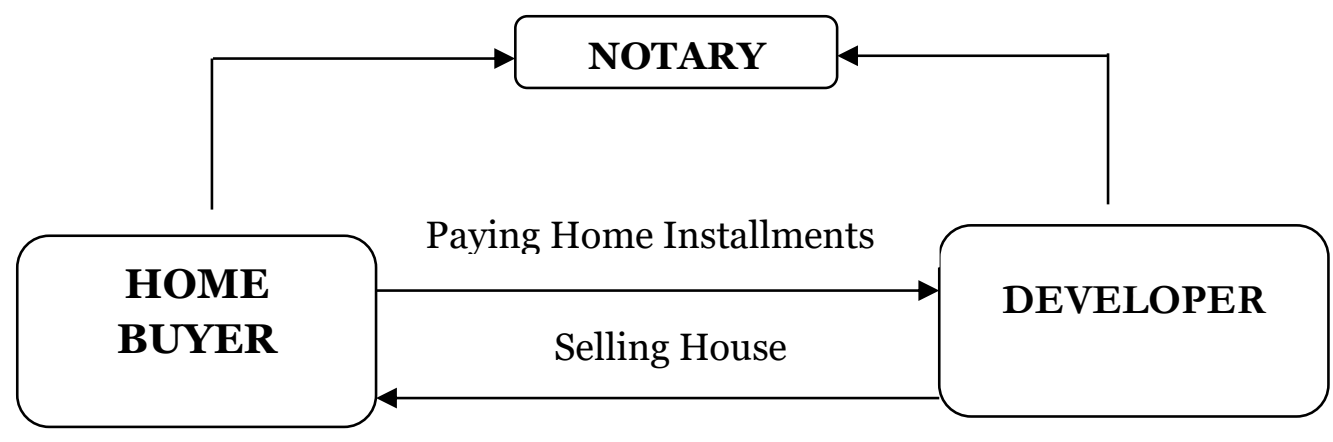

Source: (Egi Arvian Firmansyah, 2017)

Based on the scheme, it is known that the customer will directly discuss the discussion about Mortgage to the property developer, and also in payment of the loan will directly pay to the developer. As for the legality aspect only use notary services.

\section{Maqāsid Syarī’ah}

According to Jaser Auda, Maqashid Syari'ah is defined as the values and meanings that Allah SWT wants to achieve behind the making of sharia and law, which was researched by mujtahid scholars from Sharia texts (Auda J., 2007). In line with Jaser Auda, Imam As-Syatibi also said that in fact the Sharia is aimed at realizing the Mashlahah (benefit) of humans both in the world and in the hereafter. And he said that laws are prescribed for the Mashlahah for servants (Bakri, 1996).

New laws are sometimes not found in the Alquran and Hadith, so what is concerned is the purpose of syari'ah for the Mashlahah (benefit) of mankind. There is no law of Allah SWT which has no purpose, because law which has no purpose is the same as imposing something that cannot be implemented. Mashlahah in this case, is defined as everything related to human sustenance, fulfillment of human livelihoods, and the acquisition of anything demanded by its emotional and intellectual qualities, in an absolute sense. Furthermore, Imam Syatibi said that the main purpose of Maqāsid syarī'ah is to maintain and fight for three aspects of legal needs, namely covering three levels, the needs of ḍarūriyah, hājiyah and tạ̣sinniyah (Asy-Syatibi, AlMuwafaqat Fi Ushuli Asy-Syariah, 2005).

a) The Darüriyah aspect. This aspect is a basic need (basic), which is all the most important needs in human life, for the good of religion and life in the world and the hereafter. This need is known in the Shari'a as Ad-darüriyah $A l$ khamsah (the five most important things, such as safeguarding religion, soul, mind, descent, and maintaining property.)

b) The Hājiyah aspect. The hājiyah aspect is intended to remove difficulties or make the maintenance of the five constituents even better. And also to present secondary needs, namely something that humans need for spaciousness and breadth, to bear the burdens of taklif and other burdens of life. If this need is not fulfilled, it will not threaten safety, but will experience difficulties. 
Taḥsīniyah aspect. Namely Maqāsid taḥsinniyah is intended so that humans can do their best to perfect the maintenance of the five main elements. This aspect of tahsiniyyat is a complementary need. If this need is not fulfilled, then it will not threaten nor cause difficulties and will not endanger human life as would happen if dharuri was not there and also did not experience difficulties or limitations as would have happened if the hajiyyat was not available. This condition is a complementary condition of human life, so that humans feel the comfort of life. (Asy-Syatibi, AlMuwafaqat Fi Ushuli Asy-Syariah, 2005)

\section{METHODS}

This research uses descriptive qualitative methods. What is meant by qualitative methods is to understand the phenomena experienced by research subjects, and by means of descriptions in the form of words and language (Lexy $\mathrm{J}$, 2005). While the descriptive method is a method used to analyze data by describing or describing the data that has been collected as it is without intending to make general conclusions or generalizations (Sugiyono, 2013). The data used in this study are secondary data with a data scheme compiled based on literature study techniques.

Based on the research method presented above, the authors draft the research method as follows:

a. Observation of this case, with the observation of public understanding of the Home Ownership Credit products in Islamic banks. Where some people think that Islamic banks are the same as conventional banks in terms of housing loans.

b. This study focuses on housing loans in Islamic banks and housing loans without Islamic banks.

c. Collecting data in this study is a literature study, which is sourced from books related to this research problem, fiqh books, and journals.

d. Describing and analyzing the data in Maqashid Sharia Perspective.

Chart 1. Design of Research Methods

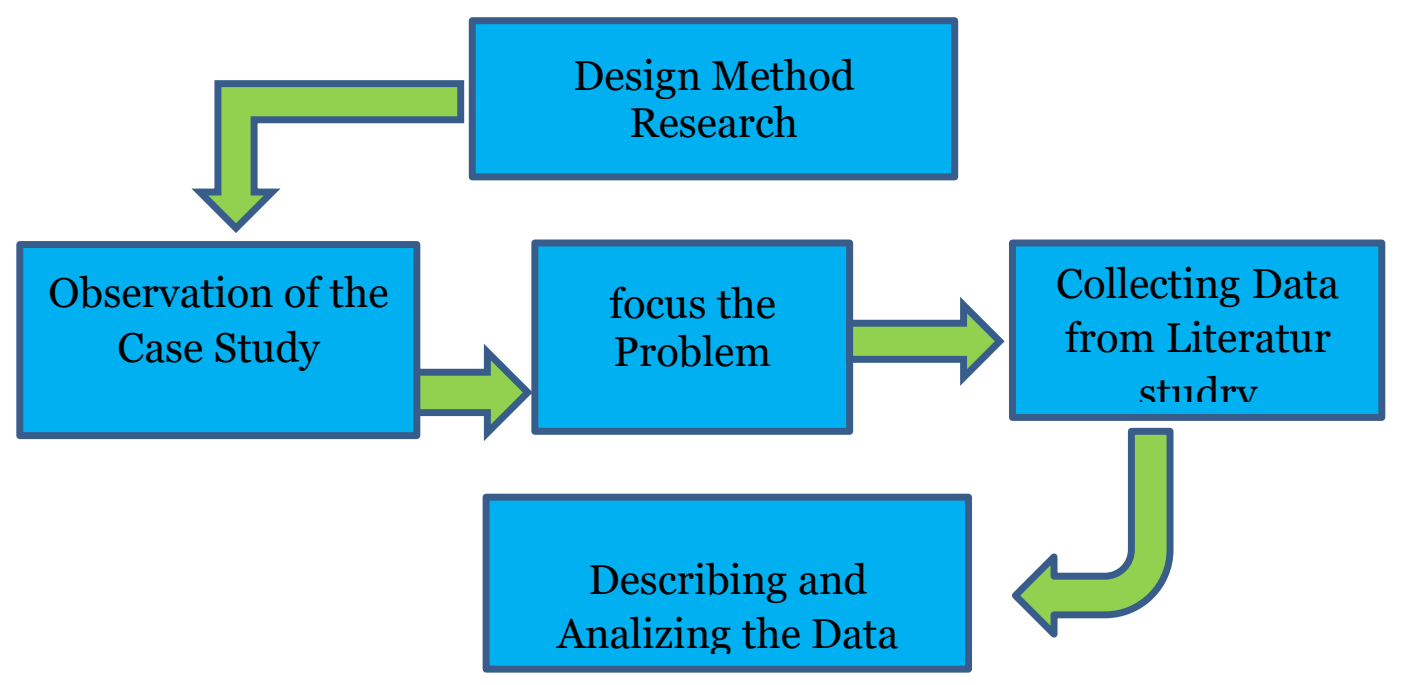




\section{DISCUSSION}

\section{Fines, Guarantees And Seized Collateral At Sharia Banks}

Sharia banks are in principle and operational differ from conventional banks, but not few consider that banking is the same as both sharia banks and conventional banks. Among those who said the Sharia bank remained haram, specially Sharia developers, the reason because it is still applying the fine, seized (Syahrul, 2020). The difference is sometimes not too well understood by the community, so that most people finally concluded that the household credit products issued by sharia banks is a product that is not different from that issued by conventional banks.

According to the Zaidi, the still aspect of riba made by sharia banking arises because of differences in public understanding. It is also directly proportional to the difference between the scholars of the law or the policy that is not contained explicit in the main source of law namely the Qur'an and Hadist (Zaidi, 2015).

In its understanding, Fines are known as Gharamah. Which means a punishment is required for the perpetrator to pay a certain amount of money or to be given sanctions in the form of prison confinement. (W.J., 2006) Fines can also be interpreted as Ta'zir, which is a punishment of lessons, and means prohibition, prevention, punishment that must be given to an offence involving the violation of the law of Allah SWT or the abuse of human rights. (Abdul, 2003). In practice, on sharia banks, fines to customers are those who are able to pay, but they deliberately delay paying. As explained in the fatwa DSN-MUI No. 17 year 2000. However, the received fines do not enter into the bank's revenue stream or are not utilized by the bank, but the fines are allocated for welfare funds or social interests. It is different from conventional banking where the Penalty fund is entered and recognized as the bank's revenue stream.

In addition to fines, sharia banking also implements collateral and seized collateral for financing submitted by customers. Understandly, according to the experts, collateral is something given to the creditor as a sign of trust or a seriousness that the debtor can fulfill its obligations that can be likened to the money raised by the accountant of an alliance. A guarantee can also be interpreted as a valuable asset that is credited as a guarantee of creditors to the debtor. (Bahsan, 2002). Sharia bank implements guarantees against the financing submitted by the customer based on the Fatwa DSN No 68-year 2008 about Rahn and tasjily and the Fatwa DSN No. 92 of 2004 on the financing accompanied by Rahn. In the fatwa-fatwa of Indonesian Ulama Council allows the guarantee of goods.

While the application of seized practice collateral is different from conventional banks. In practice Sharia banking guarantees or collateral is allowed only in case of default in the installment of the financing, the bank must first look at the reason for the inability of the client, not directly at the auction or seized i. With the process of going to the auction it takes a very long and long time, Sharia bank First look to the customers I'tikad, also see the cause of the installment congestion factor. If the congestion due to the factors outside the deliberate, the sharia bank will make an approach to the customer with the principle of deliberation to find a way out together. (IFA, 2017). 


\section{Application of BI Checking on sharia banks}

The implementation of BI Checking is also rated as differentiator between Sharia house credit ownership using a bank account with Sharia house ownership without a bank. BI Checking is the process of tracking the credit history seen in Bank Indonesia's debtor Information System (SID). And since 1 January 2018, SID was replaced with a system of financial information Services (SLIK) managed by the Financial Services Authority (OJK). The function is the same as bi Checking, only the entire service switches from BI to OJK. Thus, the IDEB SLIK aims to carry out supervision and service of financial information, which is one of the tasks of providing debtor (IDEB) or IDI historical information (Az-Zahra, 2019).

This System of Financial Information Services (SLIK) is imposed by sharia banking for customers who will carry out the financing of home ownership credit through Sharia banks. When the customer wants to apply for a mortgage financing then the right to decide whether the submission of the home ownership credit is approved by the financial Services authority (OJK). The results of the process contain financial statements, debtors' identity, collateral, owners and managers, fundproviding facilities, financing received, guarantors, and collectability therein. From here, the current or absence of customer payment can be seen clearly (KMJ, 2019).

The BI Checking process is viewed by Some people including the Sharia developers stating that the process is too long and convoluted, because it must pass through $B I$ Checking, plus the possibility of filing a household credit may be rejected or not accepted. (Syahrul, 2020). The tendency to not want the long process is to make some customers do not apply for home ownership credits through Sharia banks.

\section{Sharia Mortgage on Sharia Bank in Maqasid Shariah Perspective}

Maqasid Sharia occupies an important position in making regulations and policies in Sharia banking institutions, because without the Maqashid Sharia all financial products, regulation will lose its sharia substance. And will also experience slowdown in its development.

Maqashid Syariah in a common sense (basic) is the objectives of Sharia. These Shariah objectives are to realize the benefits of human beings in the world and in the hereafter. Human benefit is realized by maintaining five basic needs namely religion, soul, reason, descent and wealth (Mingka, 2015). This means that all aspects of life in Islamic teachings must lead to the achievement of the objectives, no exception to the economic practice that occurred in Sharia banking. The purpose of the Maqashid Sharia concept is to be applied to Islamic economics, finance, and banking. For example, Maqashid Syariah from fines in debtors who delay payments, guarantees, seized collateral, and the issuance of BI Checking.

However, there are still many people who assess sharia banking to apply Ribawi's principle in practice. This is because the level of public signings of the products in the sharia Bank is still poor. For the example on the fine, some people say that the fine is Riba Qard. But in theory and practice it has a very basic difference. 
The fines imposed by sharia banks are not in the case of riba. It is according to the definition of riba itself is to receive benefits from the debtor. The benefits of the debtor are further recognized as income by lending. However, it is different from sharia banking that fines are not recognized as income, not utilized by the bank, but entering into social funds that must be channeled for the public interest and the Ummah's welfare.

Thus, the fines for the sale-based financing carried out by Sharia banking are not recognized as revenues, but are recognized as welfare funds at the time of acceptance (Darsono et al., 2017). As well as the penalty of delay also not to be in the chapter riba, because riba is the benefit received by the debtor on the loan services given to the debtor. However, if the fine is not utilized by the lender then it cannot be said as riba according to jurisprudence rules.

كل قرض جر منفعة فهو ربا “"Every benefit taken by the creditor (the party that lends money) for its loan services belongs to the category of Riba"” (Adiwarman Karim, 2015).

The fines made by sharia banking are fines that lead to a moral education such as Ta'zir sanctions to the customers in order not to ignore their rights, in this case procrastinating payments when customers are able to provide them. As the word Imam Mawardi that Ta'zir sanction is intended to educate the customers.

"Punishment that is educational".

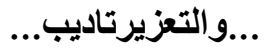

Therefore, Sharia banks are allowed to sanction to customers who deliberately procrastinate payments that has been stated in the contract agreement related fines, while referring to the fatwa DSN-MUI No. 17 year 2000 concerning sanctions on the capable customers who procrastinate payments.

In the perspective of Maqasid Sharia, implementation of fatwa DSN about sanctions on customers who delay payment aims to Avoid Mafsadah (damage), which is damage that will happen to the personal or the person who provides financing.

As said by the prophet SAW:

"'Procrastinating the payment of debt for a capable person is a wrongdoing"'”... (HR. Bukhari, Muslim,Tirmidzhi,An-Nasai, Abu daud).

So that in the Maqasid Sharia, the purpose of the enforcement of fines is to give a warning of the promise of debt that must continue to be paid, even meet and keep the promise is an obligation that must be done by a Muslim, if the client is late paying the debt when it is able to belong to the category of people who do not carry out obligations and classified Zhulm. Sanctions to customers is a form of preventing the occurrence of financial risks that will occur. Thus, the protection of financial risks is a form of property care (Hifzul-Māl). 
Then on the other hand, the person who is procrastinating payment while he can then it will affect the bank as the money manager of the customers who save in the bank, and impact on the operation of the bank. If this happens then the matter is the form of a Zhulm (tyrannical) and it must be eliminated because there is no Mashlahat (benefit).

In accordance with the hadith Rasulullah SAW:

$$
\text { لَا ضَرَزَ وَلَا ضِرَارَ }
$$

"'Must not harm oneself and cannot harm others" (HR.Ibnu Majah,Ahmad,Dan Malik).

In addition to fines, sharia banks also apply collateral and confiscated collateral in its financing practice. This is permissible in the Islamic jurisprudence; the owner of the capital can provide the customer with a number of warranties on the terms of the warranty will be disbursed only if the loss incurred due to default or negligence and to violate the conditions performed by the organizer.

As explained in the fatwa of the National Sharia Board of MUI and the international standards of AAOFI in Bahrain. Among them fatwa DSN MUI No 92 about the financing accompanied by Rahn (Assurance) that "in principle, the contract of trust is not allowed to guarantee, but so that the trustee does not commit irregularities, then the Sharia financial institution can ask the security of the trustee. And the goods can be executed if the trustee is doing a moral hazard, Such As ta'addi (ifrath) is doing something that is Not Necessarily Done, Taqshir is not doing anything that can and should be done, or violate the provisions of the provisions agreed on the parties.

In practice in Sharia banking confiscated collateral can be done if a client is experiencing delays in payment then Sharia Bank, after passing several stages of the process that helps the customer, including collectability, reconnection, process and reconditioning, then nontilation, litigation, until write off . However, if the customer is Zhalim, do delay payment then it can be subject to moral and material sanctions. And according to the Syafi'I the late pay debts, can be imprisoned, until proven trust or incapable. Not being able to mean is the poor. (Ahmad Ifham,2019).

In accordance with the Qur'an and Hadist Rasulullah SAW.

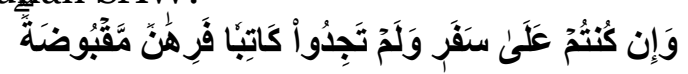

"'And if you are on the way that you do not have a scribe, then there should be a captive-held item..." QS. Al-Baqarah: 283)

Later in practice, Rasulullah SAW had bought food in debt, then he secured something to the debt. As the hadith of the messenger of Aisyah RA, said:

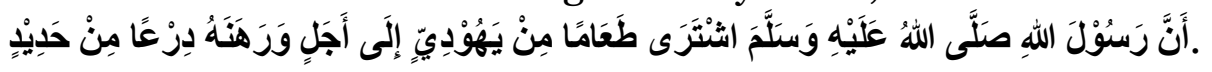

" Indeed, Rasulullah SAW bought food with a debt from a Jew, and the Prophet mortgaged an armor on him.." (HR al-Bukhari dan Muslim).

In the Sharia Maqosid, Rasulullah SAW give an example of how to regulate the possible risks by providing assurance. So, the application of collateral and seized the 
collateral provides a lesson to the customer to be serious in paying the debt to the sharia Bank. With the assurance of the application of Mortgage financing, it can provide protection against the property (Hifzul al-Māl), especially the property of the debt-giving. This is if a time of tort, there is a failed, the guarantee can be seized and executed to cover the debt of the customer.

In accordance with the hadith Rasulullah SAW:

"'Profit is in return for the readiness of loss"”.

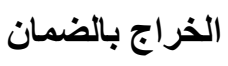

However, the aspect of $B I$ Checking which is currently changed name to IDEB SLIK is information of debtor system of financial Information Service conducted by Financial Services Authority. The purpose of this SLIK is to supervise and serve financial information of customers and other parties.

In practice, each financing submission must pass through the process of $B I$ Checking, so that in the context of the property then every property product produced and sold by the developers will be traced to various aspects, whether it is the regulations relating to the property, so that the product that has passed the process $B I$ Checking is definitely a product is halal, good product, meet the standard, and livable. for So, also in terms of finance, then the customer who has passed the process of $B I$ Checking then certainly has the ability to make installment payment for the financing submission. So, it will give security to the bank that has provided financing

According to the Fiqh, the process of analysis, the assessment is usually done as a risk mitigation, evidence of seriousness, and ensure the financial capabilities of customers as buyers. In accordance with Ibn Taymiyah's affirmation, "risk is divided into two, first, business risk, i.e. a person buys goods with the intention of selling it back to profit, and subsequently he Tawakkal. Both risks of profit, which is the risk of consuming the substance of other people in a bathed, this risk is forbidden by God and His messenger. " (Sahroni, 2019).

In Maqhosid Syariah, the purpose of the process of SLIK (Financial Information Service System) or BI Checking is to minimize the risk that may occur in the future, it is because the financial data of customers can be estimated and accounted for by the competent authorities. Then, SLIK (Financial Information Service system) help the customer to run the command of ALLAH SWT, namely fulfilling the agreement or promise.

In accordance with the orders of Allah SWT.

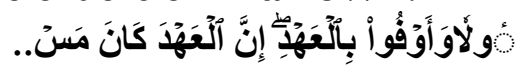

"'and fill the promise; Indeed, the promise was certainly asked for his responsibility..” (QS.Al-Isra:34)

"O believers, fill the Aqad-aqad."

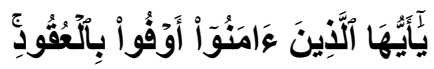

And also hadist by prophet Muhammad Peace be Upon him: 


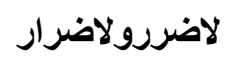

"It cannot be harmful and cannot be made to be made.."(H.R. Hakim dan lainnya dari Abu Sa’id Al khudri, H.R. Ibnu Majah dari Ibnu Abbas)

\section{Non- Bank Islamic Mortgage In Maqāsid Syarī'ah Perspective}

Non- Bank Islamic Mortgage Sharia are assessed as an alternative that can be chosen by customers who have the desire to buy a home through installment payments. Sharia-based credit without the bank claims that fine practice is not Sharia compliant, BI Checking process is too long and convoluted, so the financing process only involves the developer and the customer as the one who wants the house.

However, in the process of credit of Sharia house without the bank caused much controversy and problems faced. Based on the research from Firmansyah that the ownership credit of Sharia houses asked Bank has a greater level of fraud, even a scam is often found. (Firmansyah E. A., 2018). As happened some time ago in various areas that led to the loss of customers up to 40 billion (Tribunnews). This is because there are no parties that supervise the transaction. So that consumer protection is not well maintained due to the deed.

So, the chairman of the Central Council of Real Estate Indonesia said that consumers should be careful before buying Sharia properties. According to him, the risk of fraud on sharia properties is precisely higher than the conventional one because it does not involve banking. In fact, using banking is much safer than the risk of fraud. So that the transaction is safe and there is no lie between the client and the good developer to use banking services in this case Sharia banking (Rizki, 2020).

The financial Services Authority (OJK) said that on Sharia mortgage without a bank no one keep an eye on this property's business process (Hamdani, 2017). The property developers have only quoted the household credit that is accordance to the Islamic law, the transaction is done by the same likes each other and does not violate the provisions set in Islam. We recommend that other parties are able to supervise their practice in accordance with what is promised. For The legality aspect, the developers without a bank only involve a notary in the mortgage transactions that are carried out and consider the notary has sufficient aspects of legality aspect in the transaction activities.

Rasulullah also taught us in his Hadith:

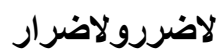

"It cannot be harmful and cannot be made to be made."(H.R. Hakim dan lainnya dari Abu Sa’id Al khudri, H.R. Ibnu Majah dari Ibnu Abbas).

The practice that can bring a Mafsadat should be avoided immediately, because it bring any harm to itself and also give harm to others. Sharia House loans without a bank do not use the BI Checking process that will provide knowledge about the customer's financial condition, it aims to avoid Zulm or mafsadat. Because when the customer enters the national blacklist according to BI Checking or IDEB SLIK then should not be offered financing that make the obligation to pay. This is because the 
customer is not financially able, and this is a client that will not be able to manage the finances properly.

In accordance with the orders of Allah SWT Al-Baqarah: 279:

لَا تَظْلْمُونَ وَلَا نُظَلَمُونَ

"Do not Persecute (to do dzholim) and are not (also) persecuted (Dzolimi)."

Rasulullah also taught us in his Hadith:

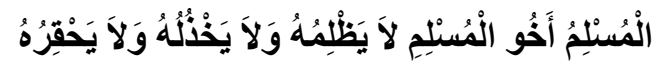
"A Muslim is a brother to another Muslim, he does not to do Zulm his brother, does not deceived him, and does not despise him". (H.R. Imam al-Baihaqi dalam as-Sunan al-Kubra, j. 8/249).

So it is necessary to see the security aspect, both security for property developers, for customer safety. The safety of customer is the purpose of the Maqaosid sharia in financial institution.

Islamic Mortgage with Sharia Bank And Without Bank

\begin{tabular}{|c|c|c|}
\hline Items & SHARIA BANK & NO BANK \\
\hline $\begin{array}{l}\text { Referring Fatwa DSN } \\
\text { MUI }\end{array}$ & Yes & Not \\
\hline BI and OJK Supervision & Yes & Not \\
\hline OJK Responsibility & Yes & No \\
\hline $\begin{array}{l}\text { Using Ideb SLIK/BI } \\
\text { Checking }\end{array}$ & $\begin{array}{l}\text { Use, in order to apply } \\
\text { Hadith لاضرورلاضرار }\end{array}$ & Not using \\
\hline $\begin{array}{l}\text { Identifying prospective } \\
\text { customer capabilities }\end{array}$ & There are legally & No legal system related to this \\
\hline Land legality & $\begin{array}{l}\text { Must be clear first for sale } \\
\text { consumers }\end{array}$ & No information \\
\hline Soil Legal files & $\begin{array}{l}\text { There must be. Protecting } \\
\text { consumers }\end{array}$ & $\begin{array}{l}\text { There are fraud facts from the } \\
\text { developers }\end{array}$ \\
\hline Developer selection & Banks are very neat in selection & $\begin{array}{l}\text { No legal selection related to the } \\
\text { developer }\end{array}$ \\
\hline $\begin{array}{l}\text { Bank-Supervised } \\
\text { Developer }\end{array}$ & Yes & Not \\
\hline Risk Management & Have & No information \\
\hline Late payment penalty & $\begin{array}{l}\text { There, halal according to the } \\
\text { Qur'an and Hadith }\end{array}$ & Nothing. Halal \\
\hline Collateral & Have. Halal & No information \\
\hline Seized collateral & Have. Halal & No information \\
\hline Problematic contract & No & No \\
\hline In case of legal issues & $\begin{array}{l}\text { OJK is involved and can ask } \\
\text { Sharia banks. It secures } \\
\text { customers as consumers }\end{array}$ & OJK is not involved \\
\hline Sharia compliant & Yes. Securing Customer Position & Yes \\
\hline Risk control & Measurable & No information \\
\hline
\end{tabular}

Sumber : (Ifham, 2019) 


\section{CONCLUSION}

The ownership of the house is usually done through intermediaries of sharia financial institutions such as sharia banks. By using some of the Akad that has been approved by the National Fatwa Council of Majelis Ulama Indonesia. However, there is currently an alternative to owning a house but without going through a bank intermediary, namely Non-bank Islamic Mortgage.

This group on behalf of themselves as a true KPR in accordance with the sharia, even in the sharia banking itself is considered the product offered is not in accordance with Sharia because it implements instruments that are assessed contrary to Islamic law, such as the existence of BI Checking, collateral, Sita collateral, and also the issuance of fines.

However, based on the previous discussion of what is imposed by sharia banks in Maqasidh Syariah and Fiqh Muamalah has been very appropriate with Islamic sharia. For example, in the application of BI Checking, it is a very good instrument to measure and see the character and the ability customer who will apply for financing. This is to maintain Maqhasid Sharia like Treasure Guard (Hifzul Mal) and keep Yourself (Hifzu Nafs).

Then, in the collateral and seized collateral applied Sharia banks also in accordance with the purpose of the sharia is to keep themselves (Hifzu Nafs). The customer when giving collateral and preparing to be seized proved to be the seriousness of the client to keep the promise of payment. It is also to minimize the risk that will occur. Even Rasulullah SAW died leaving debt to the Jews, but the prophet left the collateral, so held seized collateral. Until the sharia Bank actually do the risk management that has been done by Rasulullah SAW.

And the application of fines by sharia banks has also been in accordance with the Qur'an and Hadith and also strengthened by the fatwa DSN MUI No. 17 year 2000 about sanctions on the capable customers who procrastinate payments. And on the other hand, the funds resulting from fines do not enter into the post of Sharia bank, but is included in the Welfare Fund for the Ummah.

Therefore, the conclusion that KPR Syariah through sharia banks is more secure in Maqosidh Syariah than sharia KPR without a bank as an intermediary. Especially in providing a sense of security to customers, consumer protection, also safe from the financing management side of analysis, approval, monitoring to completion, or risk management.

\section{REFERENCES}

Abdul, A. D. (2003). Ensiklopedi Hukum Islam. Jakarta: Ichtiar Baru Van Hove. Adiwarman Karim, O. S. (2015). Riba, Gharar Dan Kaidah-Kaidah Ekonomi Syariah. Jakarta: Rajawali Press.

Ascarya. (2013). Akad \& Produk Bank Syariah. Jakarta: PT Rajagrafindo Persada. Asy-Syatibi, A. I. (2005). Al-Muwafaqat Fi Ushuli Asy-Syariah. Beirut: Daarul Kutub Al-Ilmiah. 
Asy-Syatibi, A. I. (2005). Al-Muwafaqat Fi Usuli Asy-Syariah (Vol. 1). Beirut: Beirut: Darul Kutub al-Ilmiyah.

Auda, J. (2007). Fiqh Maqasid Inasat Al-Ahkam Bi Maqosidiha. Herndon: IIIT.

Auda, J. (2011). Maqashid as-Syari’ah Dalil lil al-Mubtadi’n. Virginia: IIIT.

Az-Zahra, A. I. (2019). Ngaji Bisnis Zaman Now. Jakarta: Rafikatama.

Bahsan. (2002). Penilaian Jaminan Perbankan Indonesia. Jakarta: Rejeki Agung.

Bakri, A. J. (1996). Konsep Maqashid Syariah Menurut As-Syatibi. Jakarta: PT Rajagrafindo Persada.

Darsono Dkk, A. S. (2017). Dinamika Produk Dan Akad Keuangan Syariah Di Indonesia. Depok: Rajawali Pers.

Egi Arvian Firmansyah, D. R. (2017). Kredit Kepemilikan Rumah Syariah Tanpa Bank : Studi di Jawa Barat. Manajemen Teori Dan Terapan, 223-230.

Firmansyah, E. A. (2017). KREDIT PEMILIKAN RUMAH SYARIAH TANPA BANK: STUDI DI JAWA BARAT. Manajemen Teori dan Terapan, 223-230.

Firmansyah, E. A. (2018). A New Paradigm in Islamic Housing: Non-Bank Islamic. AlIqtishad: Jurnal Ilmu Ekonomi Syariah (Journal of Islamic Economics)., 10 (2), $313-324$.

Hamdani, T. (2017, Mei 17). OJK: Tidak Ada Pengawas Developer, Masalah Utama KPR! Diambil kembali dari Oke Zone Economy: https://economy.okezone.com/read/2017/05/17/470/1693167/ojk-tidak-adapengawas-developer-masalah-utama-kpr

Haris, H. (2007). Pembiayaan kepemilikan rumah (sebuah inovasi pembiayaan perbankan syari'ah). La Riba: Jurnal Ekonomi Islam, 113-125.

Heykal, M. (2014). ANALISIS TINGKAT PEMAHAMAN KPR SYARIAH. BINUS BUSINESS REVIEW, 5 (2), 519-526.

Hosen, M. N. (2009). Musyarakah Mutanaqishah. Al-Iqtishad : Jurnal Ilmu Ekonomi Syariah, 47-60.

Ifa, L. F. (2017). Jaminan dan Agunan Dalam Pembiayaan Bank Syariah dan Kredit Bank Konvensional. Jurnal Hukum \& Pembangunan, 134-149.

Ifham, A. (2019). Ngaji Bisnis Zaman Now. Jakarta: Rafikatama.

KMJ. (2019, Agustus 03). Mau Ngutang ke Bank? Kenali Dulu BI Checking. Diambil kembali dari Economy Okezone: https://economy.okezone.com/read/2019/03/o8/320/2027311/maungutang-ke-bank-kenali-dulu-bi-checking?page $=2$

Lexy J, M. D. (2005). Metode Penelitian Kualitatif Edisi Revisi. Bandung: PT. Remaja Rosdakarya.

Mingka, A. (2015, September 17). Maqashid Syariah Dalam Ekonomi, Keuangan Dan Perbankan Syariah. Diambil kembali dari Iqtishad Consulting: https://www.iqtishadconsulting.com/content/read/blog/maqashid-syariahdalam-ekonomi-keuangan-dan-perbankan-syariah

Muhammad. (2016). Manajemen Keuangan Syariah Analisis Fiqh Dan Keuangan. Yogyakarta: UPP STIM YKPN. 
Muhammad Rizki Hidayah, K. N. (2018). ANALISIS IMPLEMENTASI AKAD ISTISHNA PEMBIAYAAN RUMAH (STUDI KASUS DEVELOPER PROPERTY SYARIAH BOGOR). Jurnal Ekonomi Islam, 9 (1), 1-12.

Redaksi, F. (2008). Kompilasi Hukum Ekonomi Syariah. Bandung: Fokusmedia.

Rizki, M. J. (2020, January 7). Marak Penipuan Berkedok Properti Syariah, Begini Saran REI! Diambil kembali dari Hukum Online: https://www.hukumonline.com/berita/baca/lt5e147a052fo5o/marakpenipuan-berkedok-properti-syariah--begini-saran-rei/

Sahroni, O. (2019). Fikih Muamalah Kontemporer. Jakarta: Republika.

Sholihin, A. I. (2008). Ini Loh Bank Syariah! Jakarta: PT Grafindo Media Pratama.

Smolo.E \& Hasan, M. (2011). The Potentials of Musharakah Mutanaqisah For Islamic Housing FInance. International Journal Of Islamic And Middle Eastern Finance And Management, 4 (3), 237-258.

Sugiyono. (2013). Metode Penelitian Kualitatif dan R\&D. Bandung: alfabetaCV.

Syahrul, S. (2020, February 14). Mangsa dan Modus Penipuan Properti Syariah. Diambil kembali dari DetikNews: https://news.detik.com/kolom/d4899234/mangsa-dan-modus-penipuan-properti-syariah

W.J.S, P. (2006). Kamus Bahasa Indonesia. Jakarta: Balai Pustaka.

Zaidi, S. S. (2015). Standardization Of Islamic Marcet Indices Syed. Emerald Insight International Journal Of Commerce And Management, 33 (5), 883-895. 